\title{
Egalitarianism and the Returns to Education during the Great Transformation of American Education
}

\section{Citation}

Goldin, Claudia. 1999. Egalitarianism and the returns to education during the great

transformation of American education. Journal of Political Economy 107(6): S65-S94.

\section{Published Version}

http://dx.doi.org/10.1086/250104

\section{Permanent link}

http://nrs.harvard.edu/urn-3:HUL.InstRepos:2623652

\section{Terms of Use}

This article was downloaded from Harvard University's DASH repository, and is made available under the terms and conditions applicable to Other Posted Material, as set forth at http:// nrs.harvard.edu/urn-3:HUL.InstRepos:dash.current.terms-of-use\#LAA

\section{Share Your Story}

The Harvard community has made this article openly available.

Please share how this access benefits you. Submit a story.

Accessibility 


\title{
Egalitarianism and the Returns to Education during the Great Transformation of American Education
}

\section{Claudia Goldin}

Harvard University and National Bureau of Economic Research

\begin{abstract}
Secondary school education greatly expanded in the United States from 1910 to 1940, setting its schooling attainment apart from that of all other countries. Barely 10 percent of youth were high school graduates in 1910, but by the mid 1930s the median youth had a high school diploma. In some regions, by the 1930s enrollment and graduation rates rose to levels that were as high as they would be two decades later. The issue addressed here concerns the economic impact of the large increase in the supply of educated labor. Evidence is presented concerning the sharp decline in the wage premium to ordinary white-collar workers. With the expansion of the high school, large numbers of Americans competed for positions in the coveted white-collar sector. Although the return to a year of high school remained considerable on the eve of World War II, egalitarianism had evened the playing field for a substantial segment of Americans.
\end{abstract}

It is often claimed that the United States underwent three transformations in its educational history, one for each schooling level. That in primary school was a mid-nineteenth-century occurrence, that in

Presented at the Symposium on the Economic Analysis of Social Behavior, Chicago, December 1-2, 1995. This paper derives from several others of mine on the high school movement, the wage structure, and technological change, some jointly authored with Lawrence F. Katz. The findings of several recent papers have been referenced but not extensively discussed. I acknowledge the helpful comments of a referee and those at the symposium. 
high school an early twentieth-century happening, and that in college education a mid to late twentieth-century development. There may have been three transformations, but only that involving secondary schools truly deserves the appellation "great." Once underway, it was completed in a relatively short period, it involved the most spectacular increase in enrollments and graduation rates, it paved the way for the third transformation, and it set America far ahead of all nations in its educational attainment. And like the other two transformations, yet more so, it reflected and reinforced a basic precept in America-egalitarianism. ${ }^{1}$

No other country in the world achieved secondary school enrollment and graduation rates equal to those in the United States during the 1910-40 period. Youths in most European countries would have to wait decades more for their high school movements to begin. In 1962, for example, only 15 percent of all British 17-year-olds were in school. The U.S. high school graduation rate in that year was almost 70 percent (see, e.g., Ringer 1979; Goldin and Katz 1997).

The modern high school was literally invented in the United States, and it was a very American institution. Elsewhere, secondary school meant college preparatory training, except in Germany, where its vocational equivalent often meant industrial preparation. Only in America, during the first half of this century, was the academic high school intended for the majority of youth as "schooling for life" rather than for college entry. Thus, only in America could secondary schooling have greatly affected the earnings of ordinary white-collar workers in the interwar period. This paper concerns the rise of the American secondary school and its effects on the returns to education and ability from 1910 to 1940 .

\section{The Questions}

The seed for this paper was planted when I was a graduate student at the University of Chicago taking labor and applied economics. We were taught that the private rate of return to high school was substantial in 1939. But if the return in 1939 was large, what was it earlier in the century, prior to the increase in high school graduation rates? We could only speculate on the question because the first U.S. census to inquire about educational attainment was taken in 1940. I can now offer a more precise answer to the professor who

\footnotetext{
${ }^{1}$ According to the American Heritage Dictionary, egalitarianism means "affirming, promoting, or characterized by belief in equal political, economic, social, and civil rights for all people." I mean a commitment to equality of opportunity, not necessarily to the equality of results.
} 
asked that question-Gary Becker. ${ }^{2}$ The return was even higher before the great transformation in American education and was substantially reduced as high schools expanded.

The question concerning the returns to education exists largely because of insufficient data. Not only was the 1940 census the first at the national level to request information on highest grade completed, it was also the first to inquire about labor income (although not income from self-employment). For the period before 1940, researchers have uncovered and used only a handful of small and proprietary data sets, and each is somewhat idiosyncratic. ${ }^{3}$

Not only has the pre-1940 period been a statistical dark age with regard to the returns to education, but recent findings suggest that schooling data from the 1940 population census may have serious deficiencies. I have recently demonstrated that the 1940 census greatly overstates the proportion of Americans who were high school graduates (Goldin 1998, fig. 6). ${ }^{4}$ The estimated return to high school and college education is likely to be biased because of the overstated educational attainment. But the direction of the bias is not known. The return would be biased upward if the successful more often overstated their high school graduation. It would be biased downward if the overstatement in years of schooling arose from in-grade retardation or attendance in common or ungraded schools for more than eight years. ${ }^{5}$

\footnotetext{
${ }^{2}$ See also the discussion in chap. 7 of Becker (1993): "Although the relative number of both high-school and college graduates increased substantially before 1939, the former probably increased more rapidly. Supply changes alone, therefore, would produce a greater decline in the rate of return to high-school than to college graduates ... Quantitative information before 1939 is extremely scanty and unreliable"' (p. 223).

${ }^{3}$ See, e.g., Ellis (1917), Gorseline (1932), and Griliches and Chamberlain (1975) on Gorseline. More recently, Lawrence F. Katz and I have created a data set from the 1915 Iowa State Census, the only pre-1930s data set for the United States that contains education and earnings data for a large sample of individuals; see Goldin and Katz $(1999 a, 1999 b, 1999 c)$ for estimates of the returns to education in 1914.

${ }^{4}$ For native-born males born in 1910, e.g., about 31 percent claimed to have completed 12 years of schooling. The percentage who could have actually graduated, calculated by adding up all individuals graduating from public and private high schools and leaving the preparatory departments of colleges and universities, is only about 23 percent. The overstatement is larger, proportionally, for cohorts born before 1910 and smaller for those born after. For those born in 1900 the numbers are 22 percent vs. 12 percent. There are many reasons for the divergence. Most important is that respondents in 1940 probably answered the question "years of education" rather than the question asked, "highest grade completed." Because I find that differences for grade 10 are not large, I suspect that in their older years, individuals inflated their educational attainment as schooling norms changed for younger cohorts.

${ }^{5}$ In many communities, just prior to the decision to build a high school, the common or elementary schools came under pressure from parents, as well as from students, to teach upper-level subjects. It was often this type of pressure that brought about the expansion of the high school system in America, and it worked similarly
} 
The assignment, then, is to find the returns to education, particularly at the secondary level, in the pre-1940 period. Also of importance is the quantity of education and whether there is a connection between the rate of return and the educational flow. If the return to education was even higher before 1940, did the premium spark the increase in high schools and serve to produce more educated youths? If there was a spectacular increase in secondary schooling, did it cause a decrease in the premium to educated individuals? And if the premium fell, was there a switch of demand from low-educated, often foreign-born, labor to better-educated, mainly nativeborn, labor in certain blue-collar manufacturing jobs? I shall answer all three questions in the affirmative.

Information from the federal population censuses for older cohorts shows that there was a substantial increase in the highest grade completed for those born between about 1895 and 1925, who thus attended secondary school from around 1910 to 1940 . But as just noted, the 1940 census overstates the educational attainment of older cohorts, and thus the increase in education must have been even greater than that implied by the 1940 census. Further, the figures generally presented on educational attainment are those at the national level and may not be representative of the separate regions of the country. In fact, they are not. The increase in secondary schooling in many regions was far quicker and considerably more complete even by 1930 than the national data indicate.

I move, therefore, to a presentation of contemporaneous data on secondary school enrollments and graduation by region. I shall show that the "great transformation" in education occurred swiftly within each region. Some regions-for example, New England, the West North Central, and the Pacific-led the nation, and although others lagged, the high school movement spread rapidly in each, once it was firmly rooted.

\section{The Great Transformation in Education}

High schools existed in most large American cities even by the middle of the nineteenth century. Boston had Boston Latin, Cambridge had Cambridge Latin, and Philadelphia had Central High, schools that exist to this day. But most nineteenth-century American youths, if they did not live in a large town or city, did not have a secondary

in Britain (see Ringer 1979). See Goldin and Katz (1999a, 1999b) for evidence that the return to a year of common-school education beyond nine years was about zero. Thus the inclusion of these years in the total would bias downward the return to each year beyond about nine. The term "common school" refers to the one-room, ungraded schools of rural areas. 
school remotely near their domicile. When the University of $\mathrm{Ne}-$ braska, for example, was established in 1869 through the vision of Congressman Justin Morrill, there was but one secondary school in the state. The central character in Willa Cather's My Antonia, to borrow another example from Nebraska, moved from farm to city just to attend high school in 1895. Nor would most American youth have been interested in attending secondary school in the nineteenth century, for even public high schools were primarily preparatory institutions for college (as can be readily seen from the word "Latin" in many of their names). The return, therefore, was not just to the three or four years of high school. It accrued primarily to those who went the full eight additional years through college.

Secondary schools expanded in large measure because their curriculum was transformed around the turn of this century into a potentially terminal program. American high schools adapted to the needs of the modern workplace of the early twentieth century. Firms in the early 1900s began to demand workers who knew, in addition to the requisite English, skills that made them more effective managers, sales personnel, and clerical workers. Accounting, typing, shorthand, algebra, and specialized commercial courses were highly valued in the white-collar sector. Starting in the late 1910s, some of the high-technology industries of the day, such as chemicals, wanted blue-collar craft workers who had taken plane geometry, algebra, chemistry, mechanical drawing, and electrical shop. The ordinary workplace did not place much value on the additional training in Latin, rhetoric, and ancient history, which were the mainstays of the classical curriculum of the older-style high school and academy. ${ }^{6}$

At the start of the high school movement, secondary schools were distinctively American institutions: egalitarian, open, and, generally, publicly financed and provided. Nowhere else in the world did such an institution exist, although ours was later copied by almost all nations. It was egalitarian because it took all youths who completed the requisite grade or year in the elementary or common schools. It was open because attendance at it did not foreclose other options. State universities, at the time, were generally bound to accept any graduate of a high school that met the state requirements for gradua-

\footnotetext{
${ }^{6}$ I do not mean to imply that these courses did not develop the logical capacity of the mind and that they were useless for the world of business and work. But one does not find business leaders and managers asking for more students with such preparation. They did, however, ask for more students who knew about chemistry, electricity, formulas, mechanical drawing, accounting, and so on. Note that the fact that some of the high-tech industries of the late 1910s were hiring high school graduates does not mean that manufacturing in general was, at that time. Most high school graduates in the 1910s and 1920s became white-collar workers.
} 
tion. And it was publicly funded and provided by the student's home district (or tuition was paid to a neighboring district). Many of the nation's more rural states eventually passed "free-tuition" laws prior to 1920 that compelled all districts to provide funds for the secondary schooling of relevant youths even if the district did not have a secondary school. Iowa, for example, passed such a law in 1913 and Nebraska in 1907. In some states, counties were granted authority to pass similar laws, as, for example, was done in Oregon in 1911 and California in 1915. ${ }^{7}$ Without these laws, parents paid tuition to a neighboring district that had a high school, if theirs did not.

The high school movement began to assume form in the 1890s, though I shall characterize it as taking place from 1910 to 1940 because that is when enrollment and graduation figures rapidly increase. The state-level data on which I am basing this study begin in 1910, but related evidence suggests a quickening in the relevant rates around $1910 .{ }^{8}$ The movement progressed differently in cities, towns, and rural areas and spread in certain regions and states far earlier than in others. I shall leave for other papers the reasons for the expansion and its particular geographic diffusion (Goldin and Katz 1997; Goldin 1998) and concentrate here on the facts regarding the increase and its relationship to the return to high school training. I should mention, however, that the automobile and its counterpart, the school bus, were important in the diffusion of the high school in rural America and that one-half of America's population was rural as late as 1920. It is difficult to imagine the high school movement sweeping across rural America in the absence of the internal combustion engine.

Although the phrase "the high school movement" may seem to imply the existence of a coordinated set of changes, one should keep in mind that there were perhaps 130,000 school districts in the United States in 1925 and that states and the federal government together provided barely 16 percent of all kindergarten through grade 12 funds in $1925 .{ }^{9}$ Elementary and secondary education were

${ }^{7}$ The free-tuition laws have not received attention yet may have been more influential in increasing the number of high school students in a state or county than compulsory education laws at the same time. Most compulsory education laws of the period did not constrain youths to remain in high school and certainly not to have graduated from high school. The vast majority exempted youths from the maximum age of compulsory schooling who had work permits and some requisite education, such as eighth grade.

${ }^{8}$ See Department of Education (1993, p. 31, fig. 11) for data on secondary school enrollment and graduation rates for the entire United States since 1870.

${ }^{9}$ There were 127,531 school districts in $1931 / 32$, the first year these numbers were compiled by the Office of Education (Bureau of the Census 1975, series H 412). These school districts, however, were not all independent fiscal districts. Whereas in some states they were truly independent, in others the townships or counties were 
very local affairs. Educational bureaucrats, to be sure, employed tactics, including professional propagandists, to convince localities to increase their budgets. But the impetus to expand education to the secondary level was primarily a grassroots movement led by parents, employers, and even young people themselves.

The statistics on secondary school enrollments and graduates that I shall present come from an extensive set of sources, mainly the U.S. Commissioner of Education or Department of the Interior Biennial Reports, but also state reports and those of Catholic schools (see Goldin 1994, 1998). These data are contemporaneous and do not suffer from the same problems as the 1940 federal population census. Rather than being derived from the recollections of older Americans, they are taken from school surveys directly or as reported to the states. Because, with few exceptions such as Utah and the South, states in the pre-1940 period provided only scant funding to localities for education, there was no apparent incentive for schools to have overstated enrollments or numbers of graduates. These data do not appear to have missed large numbers of individuals who completed high school in the evening, summer, or later in life through means other than standard day high schools, and the General Education Development program did not exist before World War II.

The data on enrollment and graduation are expressed as rates using as the denominator the population of 14-17-year-olds for enrollment and 17-year-olds for graduation. In the schooling numbers, I have included all students in the ninth to twelfth grade range whether they were in public schools, private schools (religious and nondenominational), or the preparatory departments of colleges and universities. ${ }^{10}$ I have not included youths in rural common schools who may have attended the equivalent of ninth, tenth, or even higher grades. Not only would this have been impossible to do for even one state, but the states were dubious of the value of these extended common-school programs. And they appear justified in this judgment, for the pecuniary returns to such additional years were close to zero (Goldin and Katz 1999a, 1999b). Such individuals, if they achieved secondary school learning, would probably have transferred to a village school for further training, and if they graduated, they would be captured in the state secondary school reports.

the actual fiscal units and the school districts were merely "attendance districts." The 16 percent figure for state finance is taken from Department of the Interior (1928).

${ }^{10}$ All previous educational statistics have, I believe, inadvertently omitted students in the preparatory departments of universities and colleges even though they constitute about one-third of all private secondary school enrollments before the 1920s. Ninth graders in junior highs are also included, as are students in secondary schools of varying numbers of years, such as two- or three-year high schools. 


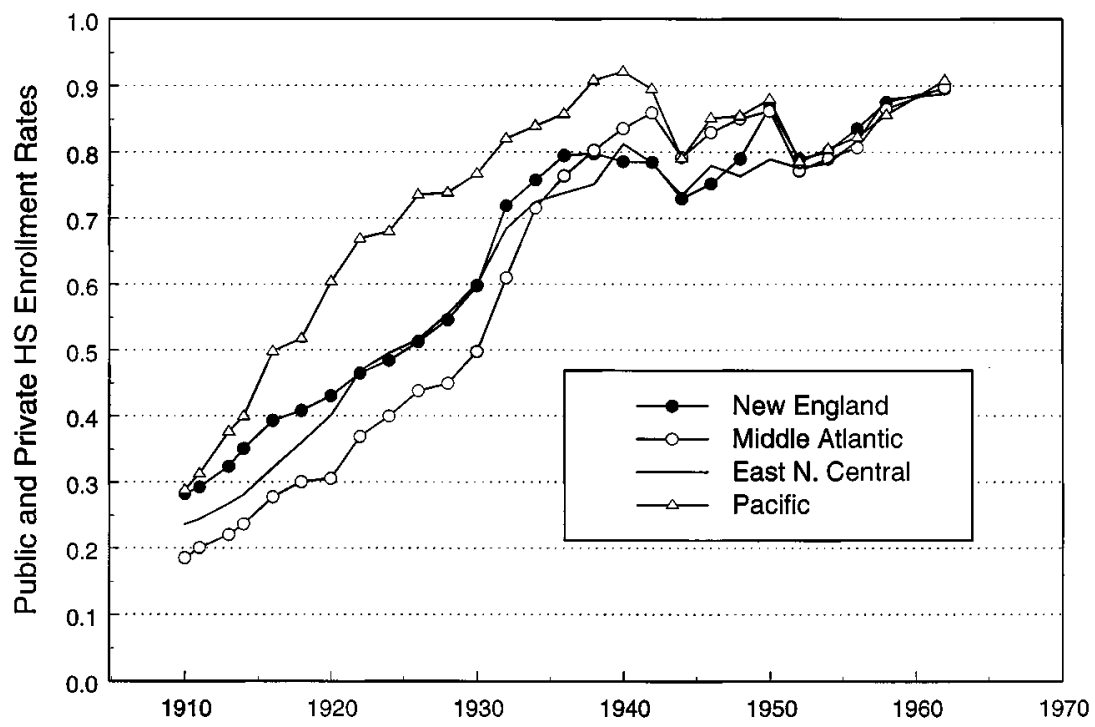

Fig. 1.-Public and private high school enrollment rates for four northern and western regions, 1910-62. Source: Goldin $(1994,1998)$. High school is defined as grades 9-12. The data are aggregated from the state level into the standard census divisions. Rates are computed by dividing the enrollment numbers for public schools, private schools, and preparatory departments by the number of 14-17-yearolds in the census division. The numbers of youths are interpolated between the census years.

I present both enrollment and graduation rates. Graduation rates are somewhat "cleaner" in the sense that most states accredited high schools and set standards for graduation, whereas enrollment rates could have been overstated for various reasons. ${ }^{11}$ Prior to the use of the "opening fall enrollment" construct in the late 1950s, enrollments were essentially the integral of student registrations over the school year and were probably slightly inflated.

The high school data for the 1910-60 period are graphed by region in figures 1,2 , and $3 .{ }^{12}$ Figure 1 presents enrollment rates for four of the nonsouthern census divisions (New England, Middle At-

${ }^{11}$ The graduation data, like those from today's secondary schools, indicate the number of youths who qualified for a high school diploma. This often meant passing a statewide examination or fulfilling certain course or credit requirements set by the state accreditation board. Because high school graduation generally guaranteed entry to the state university, states had an interest in guarding which schools could grant diplomas and which students earned them. I do not, at the current time, have information on the quality of secondary school training across the 1910-40 period.

${ }^{12}$ The figures begin in 1910 because the data are less reliable before. Evidence for the aggregate United States suggests a rather slight upward climb from the $1880 \mathrm{~s}$ to 1910 (Department of Education 1993). 


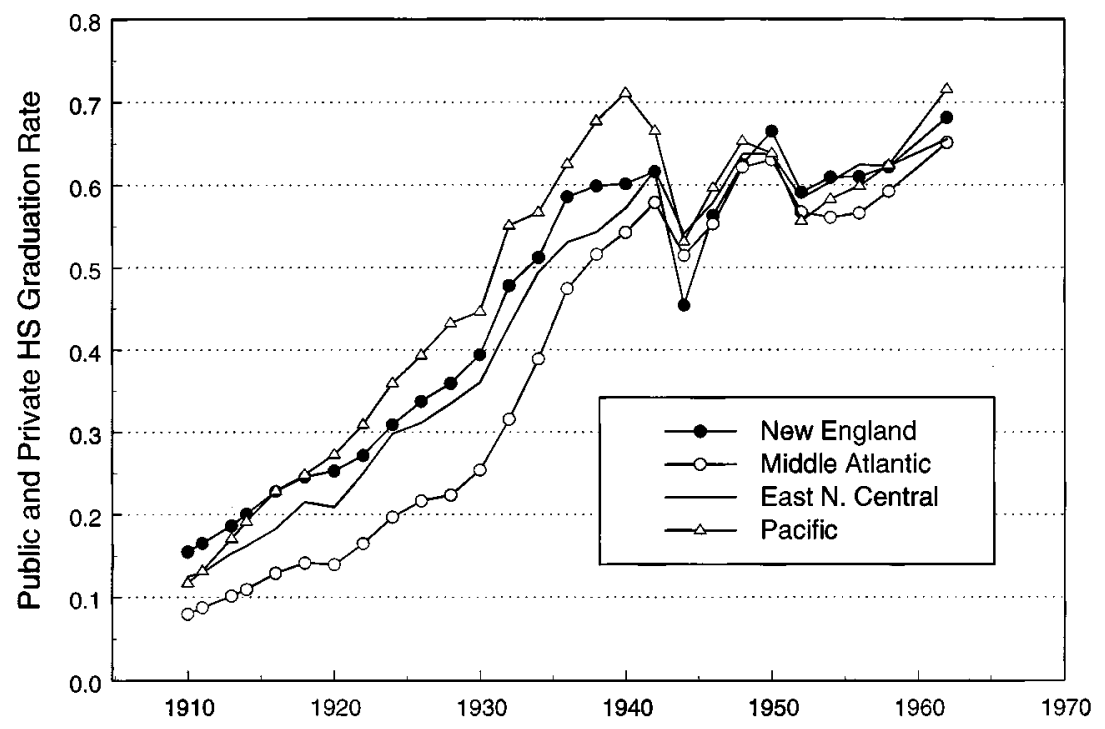

FIG. 2.-Public and private high school graduation rates for four northern and western regions, 1910-62. Source: Goldin (1994, 1998). High school is defined as grades $9-12$. The data are aggregated from the state level into the standard census divisions. Rates are computed by dividing the graduation numbers for public schools, private schools, and preparatory departments by the number of 17-yearolds in the census division. The numbers of youths are interpolated between the census years.

lantic, East North Central, and Pacific), and figure 2 contains graduation rates for the same regions. Graduation data for two census divisions in the South (South Atlantic and East South Central) are given in figure 3 together with similar statistics for the East North Central region and for whites in the South Atlantic, by way of comparison. ${ }^{13}$

When the data begin in 1910, the enrollment rate (as a fraction of 14-17-year-olds) was between 20 percent and 30 percent in the four nonsouthern divisions, with the Middle Atlantic at the low end and the New England and Pacific states at the upper end. At the same time, graduation rates (as a fraction of 17-year-olds) were un-

${ }^{13}$ The enrollment and graduation data by region, race, and sex are, to the best of my knowledge, the first of their kind produced for the United States. Although not presented here, high school graduation and enrollment rates were higher for females than for males in virtually every state and every year from 1910 to 1930 . I have omitted the West North Central and Mountain regions from figs. 1 and 2 and the West South Central from fig. 3 for reasons of clarity. Enrollment and graduation rates for the two omitted western census divisions follow paths similar to those of the Pacific states, although the increase is a bit less. 


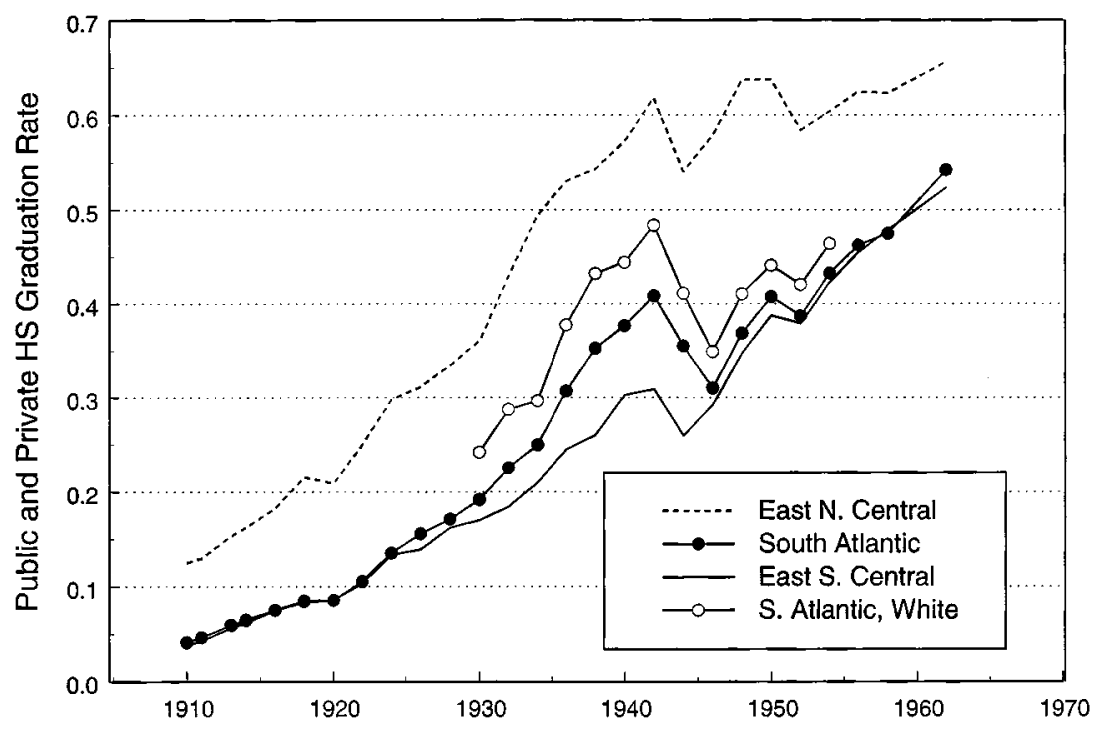

Fig. 3.-Public and private high school graduation rates for two southern and one northern region, 1910-62. Source: Goldin (1994, 1998). High school is defined as grades $9-12$. The data are aggregated from the state level into the standard census divisions. Rates are computed by dividing the graduation numbers for public schools, private schools, and preparatory departments by the number of 17-yearolds in the census division. The numbers of youths are interpolated between the census years.

der 10 percent in the Middle Atlantic and about 15 percent in New England. After 1910, both series climb steadily. The initial increase was rapid in the Pacific states, and, although slower for the other three regions, it climbed steadily. Most important, there was a marked acceleration just after 1930, so that by 1933, enrollment rates in all regions exceeded 70 percent and were more than 80 percent in the Pacific. The large decrease in both enrollment and graduation rates during World War II, especially in New England and the Pacific states, exists for both females and males. It is primarily due to the exit of youths into civilian jobs, some in the defense industries of those regions, and less so to military service.

By the 1930s, enrollment and graduation rates outside the South were extremely high and did not again increase for another 20 years. With the advantage of hindsight, one can clearly see the 1910-40 period as the sharply rising portion of a logistic function, albeit one that later increased.

A somewhat different story characterizes secondary school advance in the South. Graduation rates (also enrollment that is not depicted in fig. 3) increase here as well, but the levels are consider- 


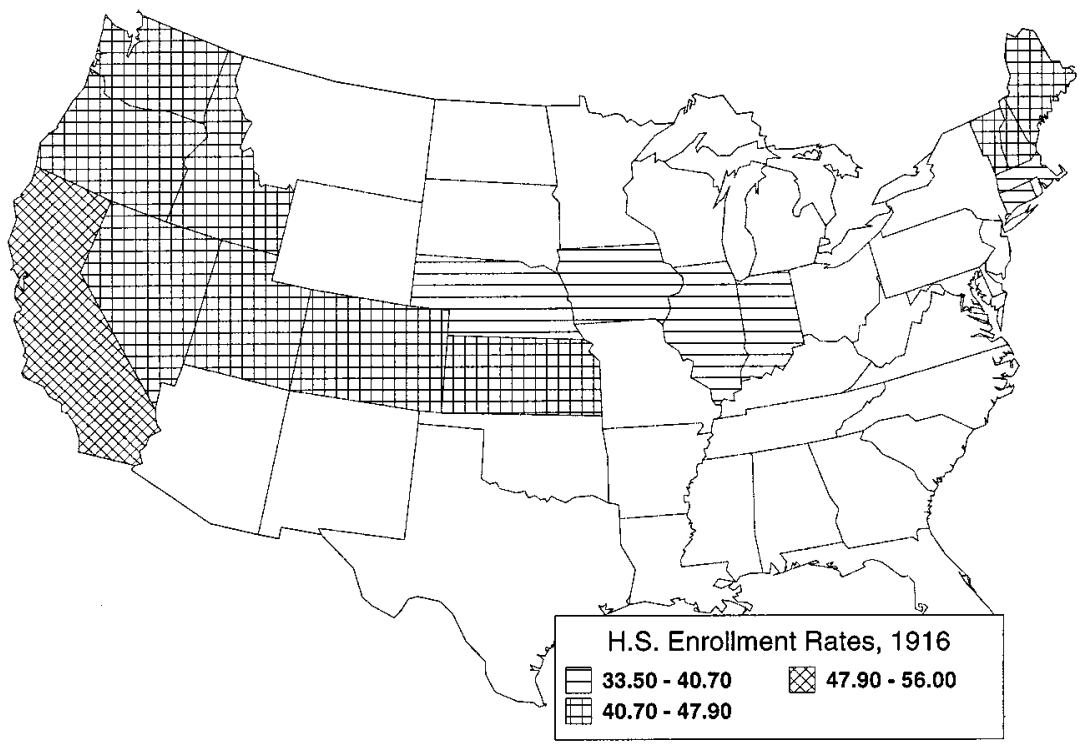

Fig. 4.-High school enrollment rates among states, 1916. Source: Goldin (1994, 1998). High school is defined as grades $9-12$. The rates are computed by dividing the enrollment numbers for public schools, private schools, and preparatory departments by the number of 14-17-year-olds in the state. The numbers of youths are interpolated between the census years. The shading of states was chosen as follows: the top one-third of the states are shaded and are arrayed by an equal enrollment rate difference among three groups (about seven percentage points).

ably lower and would be so even if the white population were considered in isolation. The Great Depression does not have the same effect on the rates in the South as elsewhere. And in contrast to the other regions, enrollment and graduation rates in the South continue to climb long after 1940.

How the modern high school diffused spatially across America tells us much about the forces that both propelled youths to attend high school and impeded them from attending. At the start of the movement, enrollment rates were highest in parts of New England. They were 35 percent in Maine, New Hampshire, and Vermont, the states that led the nation in 1910. But the leading New England region soon yielded to the rich, young, and more distributionally equal Pacific states, which eclipsed all others in a short time. By 1916, 45 percent of youths were enrolled in high schools in California, Oregon, and Washington. The movement quickly spread to another group of states (see fig. 4). In 1916, about 35-45 percent of the youths in Nevada, Idaho, Utah, Colorado, Kansas, Nebraska, Iowa, Illinois, and Indiana (listed from west to east) were enrolled in high 


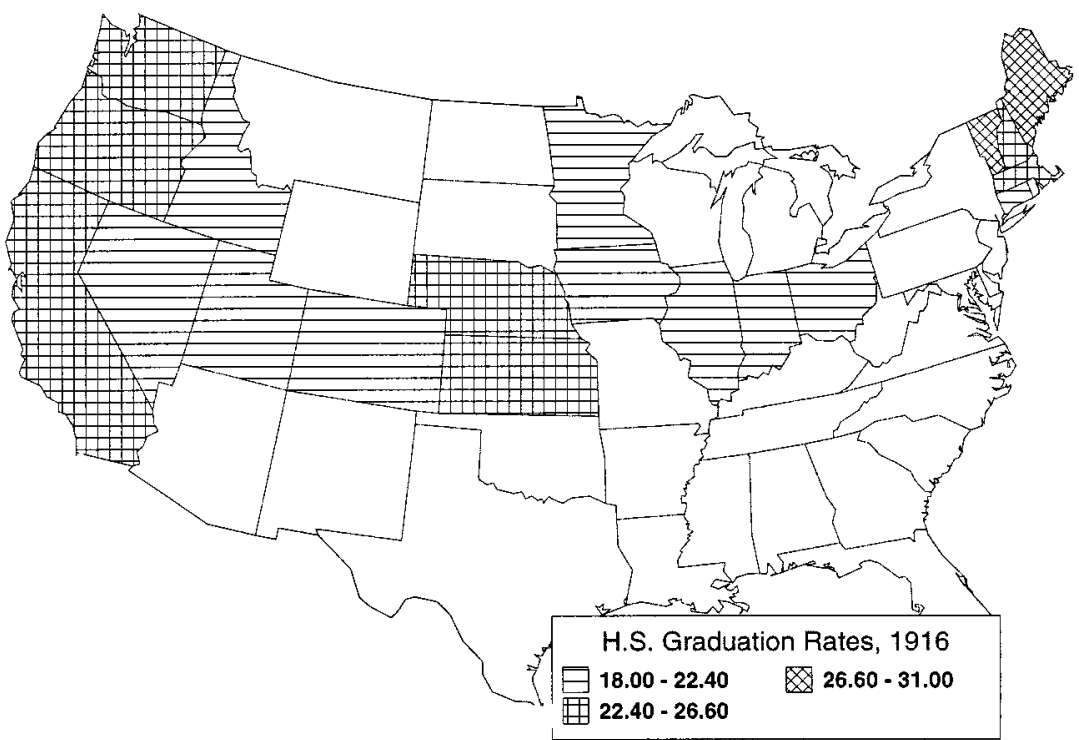

Fig. 5.-High school graduation rates among states, 1916. Source: Goldin (1994, 1998). High school is defined as grades $9-12$. The rates are computed by dividing the graduation numbers for public schools, private schools, and preparatory departments by the number of 17-year-olds in the state. The numbers of youths are interpolated between the census years. The shading of states was chosen as follows: the top one-third of the states are shaded and are arrayed by an equal graduation rate difference among three groups (about four percentage points).

school. The enrollment rates in New Jersey and Rhode Island, for example, were just 28 percent, that in Pennsylvania was 23 percent, and even Wisconsin's was just 27 percent. One does not have to look to the South to find schooling rates far lower than those in the leading states.

At the very outset of the high school movement, an "educational belt" formed across the northern portion of the United States (see figs. 4 and 5). It began in New England, jumped to the West Coast, and then spread back east through the rich heartland of America. The states in which it first took root had the richest farm, grazing, and mining land in the country. In 1922, for example, the per capita taxable wealth in Nevada was twice that in New Jersey. The richest states by this measure, on a per capita basis, were (in order) Nevada, Wyoming, South Dakota, Iowa, Oregon, California, and Nebraska. In terms of values per farm, Iowa, South Dakota, Nebraska, Nevada, and California (in order) had the highest. For the time being the movement lagged in the more industrial states of the Midwest and Middle Atlantic. High school rates were especially low in certain 


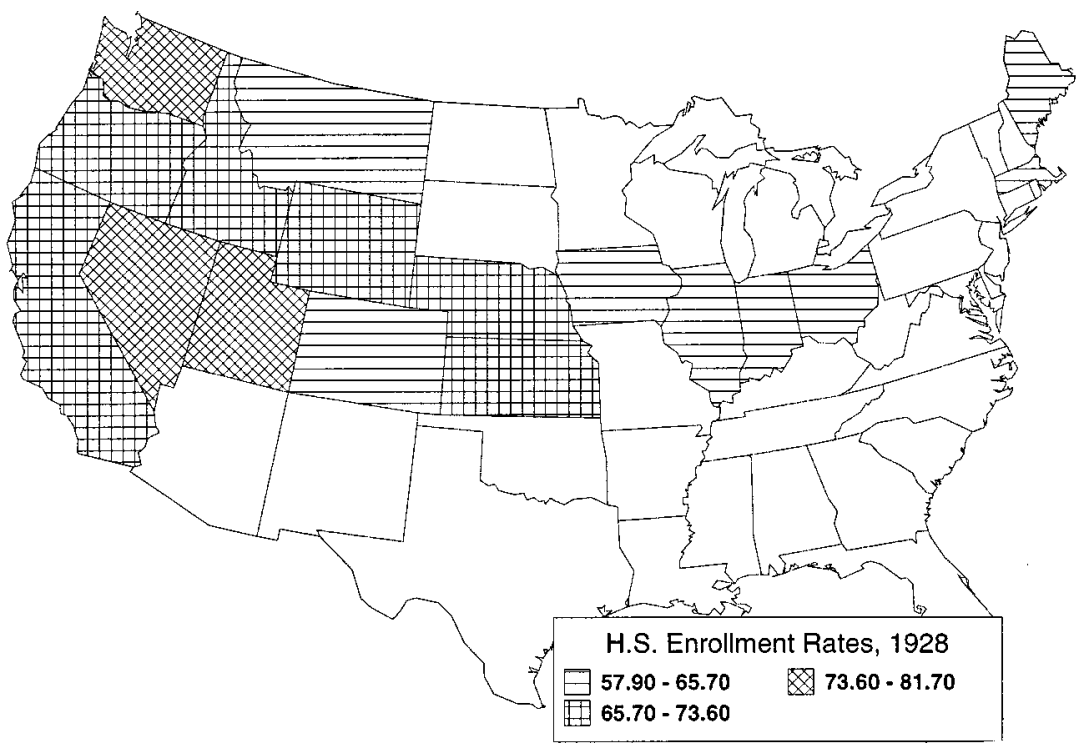

Fig. 6.-High school enrollment rates among states, 1928. Source: Goldin (1994, 1998). High school is defined as grades $9-12$. The rates are computed by dividing the enrollment numbers for public schools, private schools, and preparatory departments by the number of 14-17-year-olds in the state. The numbers of youths are interpolated between the census years. The shading of states was chosen as follows: the top one-third of the states are shaded and are arrayed by an equal enrollment rate difference among three groups (about eight percentage points).

cities of New York, New Jersey, Pennsylvania, Rhode Island, Michigan, and Wisconsin, in which older industries still flourished and youthful labor was hired. And most of the South would be left out for decades.

The same "educational belt" formed with respect to the graduation rates (see fig. 5 for 1916) and stayed in place until the onset of the Great Depression. If anything, the lead of the western and central sections of the country increased in the 1920s (see figs. 6 and 7 for 1928). In terms of graduation rates, the leading states (the darker ones) in 1928 were Washington, Oregon, Nevada, Colorado, Nebraska, Kansas, and Iowa. Wealthier states, those with relatively less employment in manufacturing, lower percentages foreignborn, and more equal distributions of wealth, achieved higher graduation rates in the pre-Depression period (see Goldin and Katz 1997).

The obvious point is that higher income and taxable wealth mattered for the advance of the high school movement, but distribution was crucial as well. Greater equality of wealth and income, given 


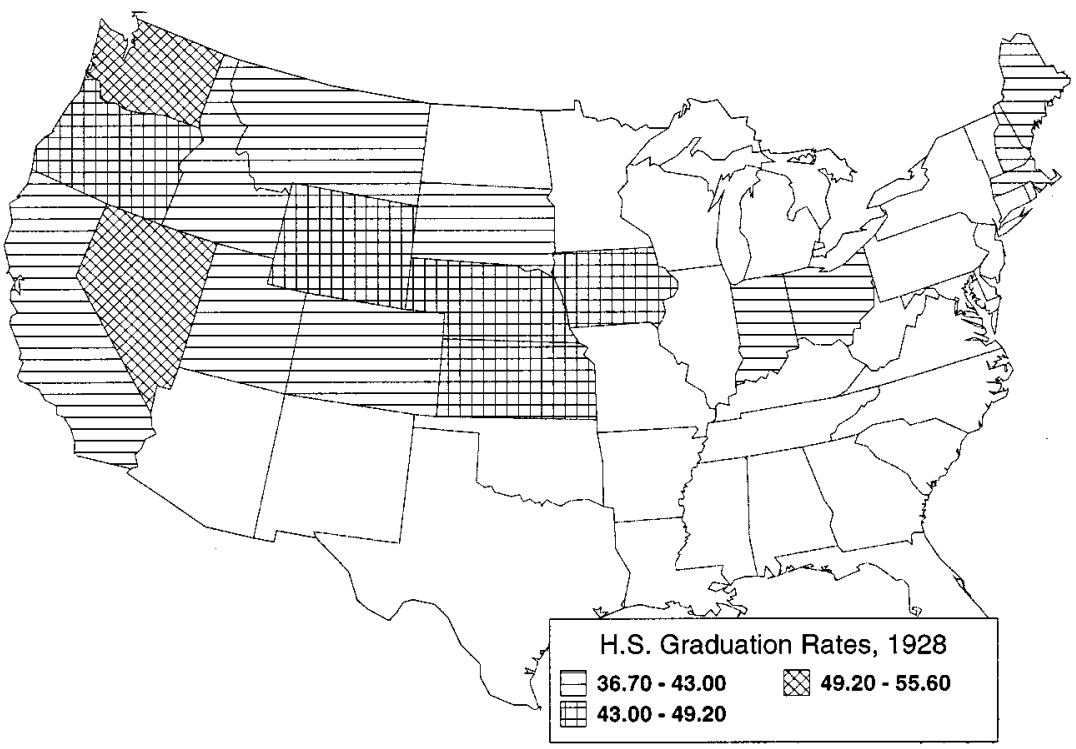

Fig. 7.-High school graduation rates among states, 1928. Source: Goldin (1994, 1998). High school is defined as grades $9-12$. The rates are computed by dividing the graduation numbers for public schools, private schools, and preparatory departments by the number of 17-year-olds in the state. The numbers of youths are interpolated between the census years. The shading of states was chosen as follows: the top one-third of the states are shaded and are arrayed by an equal graduation rate difference among three groups (about six percentage points).

some modicum of both, hastened the spread of secondary schools. ${ }^{14}$ And the greater the opportunities for immediate youthful employment in manufacturing, the lower high school enrollment, even when the proportion foreign-born in the population is held constant.

Both income and substitution effects were operating. The income effect (e.g., higher agricultural income and greater income from manufacturing) led to more youths in school. The substitution effect (e.g., greater youth opportunity possibly with higher manufacturing wages) led to fewer youths in high school.

I am also invoking a third effect: what I shall term the "homogeneity" effect, which, given the level of wealth, increased schooling. Its

${ }^{14}$ Goldin and Katz (1997) proxy the distribution of wealth in the 1920s through variables such as the number of automobile registrations per capita and values per farm. Automobile registrations per capita, for the 1920 s at least, are essentially a count of the fraction of people whose income was above some level and thus were wealthy enough to own a car. Such individuals were also wealthy enough to have supported the building of a high school. 
importance derives from the public nature of education. In jurisdictions with a wide distribution of income or wealth, the lower tail of the distribution may not want to vote tax dollars for secondary schools, and the upper tail may want to send their children to private schools, unless the public school is of very high quality. Thus a wide distribution of income or wealth can stifle the spread of secondary schools. ${ }^{15}$ Homogeneity can also refer to the ethnic and religious composition of the jurisdiction. Diverse ethnic and religious groups may be unable to agree on the type or level of schooling. Finally, homogeneity can also mean the stability of communities in which the older generations look on the younger as members of their extended families. Thus places that have a sufficiently large group of older, established, and well-to-do citizens will have greater support for public education. ${ }^{16}$ Jurisdictions that were more homogeneous, had lower income inequality, and had greater community stability had the highest levels of high school enrollment and graduation (Goldin and Katz [1997]; also see Goldin and Katz [1999a, 1999b] for an in-depth study of Iowa).

What happened with the onset of the Great Depression is telling with regard to the forces that had impeded high school attendance. As is evident in figures 1 and 2, enrollment and graduation rates increased sharply in the Middle Atlantic states with the onset of the Depression. The increase is also apparent in the New England and East North Central regions but is not as marked. The ranking of states in the enrollment or graduation rate hierarchy is not much altered by the sharp increase, but the absolute difference between the northern laggard and leading states narrows substantially. Between 1928 and 1938, Delaware, New Jersey, New York, and Pennsylvania, all hard hit by the unemployment of the Great Depression, experienced increases in their graduation rates that were among the greatest on a percentage point basis. Gains were on the order of 30 percentage points. The increases during the 1930s do not represent mere catch-up because the South experienced only slight increases

\footnotetext{
${ }^{15}$ See, e.g., Fernandez and Rogerson (1995) and Epple and Romano (1996), who build on Stiglitz (1974) and model the role of the income distribution in educational equilibria. Both present models in which there is an "ends against the middle" equilibrium. In both papers a larger middle-income group and a higher level of wealth relative to schooling costs will, in some range, advance publicly funded education. Because Fernandez and Rogerson allow public education to be "topped off" by private schooling, they get around the problem raised by Peltzman (1973) that public provision can "crowd out" private schooling and reduce the total quantity of schooling consumed.

${ }^{16}$ See Poterba (1997) for a contrasting finding using more recent data. Poterba finds that more rapid growth in the percentage elderly is associated with a smaller increase in spending on education per child.
} 
and actually fell further behind. Rather, the increase in secondary school enrollment and graduation rates in the Middle Atlantic region reflects the fact that certain manufacturing jobs had been strong enticements for youths to drop out of high school. The sudden lack of manufacturing jobs, possibly reinforced by the National Industrial Recovery Act codes, which made the hire of youths in manufacturing illegal, was an equal inducement to remain in school. The Great Depression may have had one positive effect: it enticed youth to stay in school. ${ }^{17}$

The great transformation in American education was so rapid in most states and regions that by the end of the 1930s high school graduation and enrollment rates were equal to those of the late 1950s. The South, with some exceptions, remained the outlier, although its eventual gains from the 1940s to 1950s would enable it to catch up. It is interesting that, although the South was a laggard, its secondary school enrollment rate was ahead of that in most European countries from 1910 to 1940 . Of most importance to the central question of this paper, that regarding the return to education, is that the supply of educated workers rapidly expanded from 1910 onward.

\section{The Return to Education and the Great Transformation}

What enticed American teenagers to remain in school in the 191040 period, and what was the impact of their increased schooling on the economy? Sweeping transformations of the period figure prominently in explanations for the high school movement (see, e.g., Trow 1961). The rise of big business, for example, a late nineteenth-century phenomenon, increased the demand for managers and ordinary clerical workers, and the increase of large-scale retail trade, as reflected in the appearance of the department store and the mailorder house, for example, increased the demand for an educated sales force.

But until recently there were inadequate data on the wages of workers whose positions required education beyond the elementary

\footnotetext{
${ }^{17}$ Changes in compulsory education laws do not seem to have been the cause either. New York State already had legislation (termed "continuation-school legislation") that required youths below some age (generally 16 years old) to continue in school for some number of hours a week if they dropped out and were working. New Jersey passed a law in 1931 that increased to eighth grade the education required for a labor permit for those under 15 years old. But such laws generally did not increase the graduation rate by much. Neither Delaware nor Pennsylvania passed laws with significant changes just preceding or during the Great Depression.
} 
grades or common-school ages for the 50 years before 1940. In a recent paper, Lawrence Katz and I produced the first long-term series on the wages of ordinary white-collar workers (mainly clerks, typists, secretaries, and bookkeepers) for the 1890-1940 period that separates male and female workers, as well as managers from ordinary white-collar workers. We were also able to produce similar data for individual occupations, such as typists, stenographers, bookkeepers, and clerks. These data are used to compute the ratio of the wage of ordinary white-collar workers to that of production workers in manufacturing. And it is the level of this ratio and its change over time that will provide part of the evidence regarding why the high school movement began and the impact it had. ${ }^{18}$

The first issue to address is why the premium to wages for particular occupations should represent the earnings differential arising from secondary schooling. Ordinary white-collar jobs customarily had an entry requirement of several years of high school or a high school diploma, whereas most ordinary production work had no such entry requirement in the 1900-1920s era. In the early 1900s, many large firms began to follow the hiring directives of personnel consultants. Personnel manuals reveal the advice offered as well as the stated practices of firms (see, e.g., Nichols 1927). The U.S. government was a large employer of ordinary white-collar labor, and information exists about its entry requirements (Congress 1929). The advice given to teenagers and the jobs high school graduates immediately took after graduation, as well as the occupations pursued by those with only an eighth-grade education, can also be ascertained (see, e.g., Edgerton and Cunliffe 1924). The high school graduate in the 1920s and for sometime after, particularly if female, was disproportionately bound for ordinary white-collar work unless destined for college. The eighth- or ninth-grade graduate, on the other hand, was bound for a life as a blue-collar worker, unless selfemployment was an option. ${ }^{19}$

Table 1 gives the various wage series for white-collar office workers divided by the corresponding wage for production workers, both by sex for various segments in the 1890-1939 period. The underlying data for all the series are in Goldin and Katz (1995, tables 1-4). The

${ }^{18}$ See Douglas (1930) for a similar white-collar wage series. The drawback of the Douglas series is that his data combine men and women, as well as clerical and managerial positions.

${ }^{19}$ Surveys of high school graduates in the 1910 s reveal that the vast majority planned to become white-collar workers (see, e.g., Burdge 1921). A small group of high school graduates planned to enter blue-collar occupations, particularly skilled jobs in the metal trades. I should note that clerical employment was often open to many who had several years of high school but no diploma, and most sales jobs were as well. 
TABLE 1

Education-Skill Premium, 1890-1939: Clerical and SUPERVISORY WORKERS

\begin{tabular}{|c|c|c|c|}
\hline \multirow[b]{2}{*}{ YEARS } & \multicolumn{2}{|c|}{$\begin{array}{l}\text { Clerk Wage/ } \\
\text { Production } \\
\text { WORKer Wage }\end{array}$} & \multirow{2}{*}{$\begin{array}{c}\text { CLERK AND SUPERVISOR } \\
\text { WAGE/PRODUCTION } \\
\text { WORKER: MALES } \\
(3)\end{array}$} \\
\hline & $\begin{array}{c}\text { Males } \\
(1)\end{array}$ & $\begin{array}{c}\text { Females } \\
(2)\end{array}$ & \\
\hline $1890 / 95$ & 1.691 & 1.891 & 2.392 \\
\hline $1909 / 14$ & 1.673 & 2.014 & 2.349 \\
\hline 1919 & 1.202 & 1.525 & 1.821 \\
\hline 1923-29 & 1.112 & 1.477 & 1.622 \\
\hline 1939 & 1.150 & 1.557 & 1.656 \\
\hline
\end{tabular}

Source.-Clerk (clerk and supervisor) wages: Goldin and Katz (1995, table 2); production worker wages: Goldin and Katz (1995, table 3).

Note.-Wages are averaged over the years given and ratios are then computed.

white-collar series was produced using 10 different sources, including censuses of manufactures and state surveys, each based on large samples of workers. ${ }^{20}$ Because individual occupations were listed in three of the sources, I can also examine wage changes holding the white-collar occupation constant.

The ratio of ordinary white-collar to production worker wages, as can be seen in table 1, started high in 1890/95, when it was 1.7 for men and 1.9 for women. Including managerial workers in the whitecollar group increases the ratio to 2.4 for men. The ratio remained at about this level to the immediate pre-World War I period. With the sharp and general decrease in the skill differential due to the war, the ratio plummeted to 1.2 for males (to 1.8 including managers) and to 1.5 for females. It remained at about its new level or fell further by the mid to late 1920s (for males to 1.1 for the ordinary white-collar workers and 1.6 for the more inclusive group). The ratio then stayed at the new level to $1939 .^{21}$

${ }^{20}$ The data sets include the Census of Manufactures for 1900, 1909, 1914, 1919, a Commissioner of Labor report, the reports of the Interstate Commerce Commission, various state surveys, and a Women's Bureau survey. One comparison that cannot easily be made, however, is that concerning geographic variation. The data do not enable a consistent set of wage measures for the South vs. the North or for the West vs. the East. The bulk of the data pertain to large cities.

${ }^{21}$ For both white-collar and production workers, the wages pertain to full-time employment and do not correct for changes in hours that may have differentially affected production and nonproduction workers. A correction would probably serve to diminish the reduction in the ratio, but not by much. For example, the hours of production workers declined from about 52 to 47 from 1909 to 1926 . If the hours of ordinary white-collar workers remained the same and if the 1926 hours of production workers are constrained to be the same as in 1909, they would decline from 1.673 to 1.230 (rather than to 1.112 ). Although there is strong evidence regarding the hours of production workers, there is none for nonproduction workers. 
It is tempting to use the ratios to produce an estimate of the rate of return to a year of high school. But an important assumption of the procedure is violated by the fact that some without high school worked in a higher-risk sector (e.g., self-employment) and earned, on average, more than in manufacturing jobs. ${ }^{22}$ Thus the estimated rate of return levels will be overstated, although the direction of change will not. There are, as well, other factors to consider when interpreting changes in the ratios as changes in the rate of return to education. Because enrollment rates increased substantially between 1910 and 1940, the difference in education between ordinary whitecollar and production workers must have been reduced. The junior high school, for example, was invented in 1909 as a means of retaining to ninth grade youths not destined to graduate from high school. ${ }^{23}$ The educational difference probably narrowed from four years in the pre-1920 period to three years in the post-1920 period. The difference in education between the two groups must have been somewhat more than three years in the mid 1920s because it was three years by $1940 .^{24}$ Thus the education premium would have fallen, to some extent, simply because the difference in years of education between the two groups was reduced.

The education premiums implied by table 1 do not fully take into consideration another reason to have attended and graduated from high school. In 1910 nearly 50 percent of all high school graduates

\footnotetext{
${ }^{22}$ Consider obtaining the rate of return $(r)$ to a year of high school using $r=$ $\log _{e}(R) / 4$, where $R$ is the white-collar wage divided by the blue-collar wage. The procedure would be correct if (i) the two employee groups represent individuals whose educations differ by four years, (ii) there are no ability differences between the two groups, (iii) there is no tuition or other direct costs of education, (iv) the worker's earning life is independent of years of schooling or the postschool working life is very long, and (v) all individuals with the lower level of education are in the lower-wage group and all individuals with the higher levels of education are in the higher-wage group (see Mincer 1974). The problem with applying the procedure is that assumption v is violated. Proprietors, e.g., can be drawn from the lower education group, and luck, fortune, or raw ability will enable them to earn far more than had they pursued the lower-risk, blue-collar occupation.

${ }^{23}$ The first public junior high schools were in Columbus, Ohio, and Berkeley, Calif., both in 1909. The junior high school quickly spread throughout American cities. In 1923, 47 percent of U.S. cities with populations greater than 20,000 located in the nonsouthern states had at least one public junior high school. Within these cities, moreover, public junior high schools were 60 percent of all schools offering instruction in the secondary grades (Department of the Interior 1927).

${ }^{24}$ The 1940 federal population census Public Use Microdata Sample (PUMS) reveals that the group of male, 18-34-year-old "clerks and kindred workers" (store clerks are excluded) had a median education of 12 years and a mean of 11.72 ( $n$ $=13,188)$. The group of bookkeepers, typists, secretaries, and stenographers had a median of 12 and a mean of $12.75(n=2,634)$. A similar group of production workers had a median of 9 and a mean of $9.27(n=37,692)$, with craft workers excluded. Including the craft workers increases the mean to $9.33(n=48,132)$.
} 
(male and female, public and private) intended to continue with some type of higher education, and probably a large percentage did so. ${ }^{25}$ The figure was 46 percent in 1923 and 25 percent in 1933 (Goldin 1998, table 2). The full return to high school should also include the expected value of the option of attending college and other forms of higher education (e.g., library, nursing, or normal schools). Though some individuals in the managerial group, and even some secretaries in the clerical group, did continue to college, the omission of most professional occupations will bias downward the implied return to high school when the data from table 1 are used.

It might be argued that the decrease in the skill premium after 1920 was due to a change in the mix of occupations in the ordinary white-collar category. To assess this, Katz and I have looked as well at the wage of specific white-collar occupations, by sex, compared with that for production workers. We find decreases in the premium within detailed occupations similar to those we found in aggregating across them. The occupations we are able to look at in the 18951939 period include some that did not experience major technological change (e.g., typists) and one that may have, bookkeepers. The premium to female clerical workers fell along with that of male clerical workers, and the premium to specific occupations fell as well. The ratio, for example, of the wage for female typists and stenographers to that for female production workers was 2.1 in 1895 but was 1.64 in 1926 and 1.65 in 1939. That for male typists and stenographers was 1.64 in 1895 but 1.32 in 1926 and 1.1 in 1939. Changes in neither the mix of occupations nor the sex of the workers affected the premium to white-collar workers.

The decrease in the premium to white-collar workers in the immediate post-World War I period appears to have been caused by the large increase in high school-educated workers. The supply of educated workers (proxied by high school graduates) shifted out by 16 percent in the 1890-1910 period according to our estimates, and then by 40 percent from 1910 to 1920, at the outset of the high school movement (Goldin and Katz 1995, fig. 2). The sharp increase in the supply of educated workers coincided with the decline in the premium to ordinary white-collar workers of about 30 percent, from the figures in column 3 of table 1 . Thus it appears that the large reduction in the premium to educated workers may have been

\footnotetext{
${ }^{25}$ We do not know the exact percentage because the enrollment figures for institutions of higher education include both graduates and undergraduates. The reason is that professional schools in 1910 did not often require an undergraduate degree. Various calculations I have made trying to correct for the possible double counting of those getting their second degree give estimates in the 40-50 percent range for around 1910.
} 
brought about by the sudden increase in their supply, although other factors could have been reinforcing.

One may wonder how much of the decrease in the premium was due to the closing of immigration in the early 1920s, another major change coinciding with those just mentioned. Katz and I find that the immigration quotas can account for only a small fraction of the decline in the premium. The reason is that although immigrants increased the supply of unskilled workers in the prequota period, the existing stock of potential production workers was extremely large. Thus the curtailment of immigration had a small effect on the education premium. The high school movement, on the other hand, greatly increased the numbers of more skilled workers because the stock began at a low level. Thus the effect on the skill premium of the increased supply of educated labor was much larger than that of the decreased supply of lower-skilled labor through restrictions on immigration. Had we used, instead, the wage of lowerskilled workers as the denominator rather than that of manufacturing production workers, restrictions on immigration would have accounted for a somewhat larger fraction of the reduction of the premium. We use as our comparison group all manufacturing production workers because the average elementary or junior high school graduate was likely to have found long-term employment in manufacturing. Thus the average wage for a cross section of workers is the most relevant, not just for those at the lowest rungs of the ladder.

Another potential factor affecting the premium to educated labor was technological change in the office. A virtual explosion of office machinery and new office techniques occurred from 1910 to 1930. The typewriter, comptometer (calculator), dictating machine, mimeograph, addressograph, and that precursor of the computer, the card punch machine, became standard office equipment in the first several decades of this century. New techniques-such as filing systems, carbon copies, and a finer division of labor-were equally important in transforming the office (Beniger 1986; Yates 1989; Cortada 1993). The question is whether these new machines and techniques led to a downgrading in the quality of office personnel and, therefore, to a reduction in the apparent premium to education. The issue is whether office workers had to be more able in the premachine period and became less able as machinery spread.

The answer, I believe, is that the large decrease in the premium cannot be due entirely to a change in the quality of the white-collar workforce. The data assembled on the wages for individual occupations show that the occupations that should have been least affected by technological change experienced the same relative reduction in 
earnings as those that may have been. Typists, for example, used machinery in 1925 that was not unlike that used in 1895 . Bookkeepers, however, may have used equipment in 1925 that conserved on certain abilities, such as adding long columns in one's head. These "human calculators," as they were called, could have received large premiums before the advent of the calculator but had skills that were replaced by adding machines after their invention. Yet the premium to ordinary white-collar workers fell about equally across the various occupations. I should also note here that many elementary schools in the early 1900s taught the fine art of adding long columns in one's head in response to the large premium to those who had these skills. Machinery was only one, and possibly a small, part of the declining premium to bookkeepers. Most important, the decrease in the premium to ordinary white-collar work occurred swiftly and rather completely across the occupation distribution.

Even though de-skilling technological change was not the central factor behind the decrease in the premium to ordinary white-collar workers, technological change, it appears, greatly expanded demand for them. In 1900, less than 5 percent of all nonagricultural employees were clerical workers, in 1910, 8 percent were, and in 1920, 11 percent were. Much of the expansion was due to the increased supply of educated workers, and that is why the relative price of ordinary white-collar workers plummeted. But technological change enabled education to substitute for ability. Firms, in turn, expanded the range of tasks given the ordinary office worker and thus increased demand for them.

Even though the series on ordinary white-collar workers is highly suggestive of the impact of the high school movement and the reasons why there was a large incentive to get a high school education in 1910, I have not yet presented direct evidence on the rate of return to a year of high school. The main reason is that the data demands are much greater than those required to produce skill ratios. These demands are met by only a few data sets before the 1930s, only one of which is large and representative of a substantial cross section of Americans. That data set is taken from the 1915 Iowa State Census, which asked all individuals living in Iowa their years of education by type of schooling (common, grammar, high school, and college) and annual labor income, among other variables. I have recently drawn a large sample from the extant manuscripts of the 1915 Iowa State Census. The return to a year of high school, calculated for male nonfarm workers between 18 and 34 years old, was around 12 percent (see Goldin and Katz 1999a, 1999b) ${ }^{26}$ Therefore,

\footnotetext{
${ }^{26}$ A standard log annual earnings equation was estimated that included a quartic in potential experience, an interaction between foreign-born and years in the United States, and dummy variables for native-born, nonwhite, and whether years
} 
the returns to a year of high school in 1915 were as high as returns to a year of college recently. It is no wonder, then, that the demand for public high schools was enormous even in rural America in $1915 .{ }^{27}$

In sum, the high school premium for young men was substantial before the early 1920s. The ratio of the earnings of ordinary whitecollar workers to those of production workers was 1.7 in $1909 / 14$, and including managers in the white-collar group increases the ratio to 2.4. But by the mid to late 1920 s the ratio was just 1.1 for the first group and 1.6 for the more inclusive group of white-collar employees. Note that even though the premium plummeted, the rate of return to high school education for both young men and women remained substantial in 1940. Further, the return to high school was not just what could be garnered with high school years or diploma. There was also the possibility that the youth would continue in college and receive an even greater reward.

If the return to educated labor in white-collar positions plummeted from the mid 1910s to the 1920s, blue-collar positions should have been tailored to fit the new educated, and now relatively cheap, labor force. Substantial evidence has recently been assembled to show that the newer, fast-growing, high-technology industries of the day began to employ large numbers of young, male high school graduates as blue-collar workers, probably as early as the 1920s (Goldin and Katz 1996, 1998). The 1940 census reveals that among young, male blue-collar workers, a disproportionate share were high school graduates in industries such as electrical machinery, petroleum refining, photographic and scientific equipment, aircraft, shipbuilding, certain chemicals, business and office machinery, and various

in the United States was missing. Years of education were entered by type of schooling, and years of elementary school (common and grammar separately) were entered as a linear spline function to test whether years above nine were valued differently from those below 10 . The years of college variable was interacted with whether the person listed years of high school, and a dummy variable was included for having college but no high school. The number of observations for males 18-34 years was 5,169 . The return to a year of high school for females 18-34 years old, estimated in the same fashion, was 12.5 percent.

${ }^{27}$ The comparability of the Iowa 1915 estimates with those for the 1940 federal census has been recently assessed in Goldin and Katz (1999a, 1999c). Both the income and the education measures differ between the Iowa and the federal censuses. The federal census excluded self-employment income, but the Iowa census included it. The Iowa census requested detailed information on education by level, whereas the federal census did not. Although the federal census was supposed to inquire about highest grade completed, many respondents apparently answered a question on "years of education." Most important, the 1940 census contains a very thick lower tail of extremely low-income workers. After adjusting the estimates from the 1915 Iowa State Census for comparability with the 1940 federal census, we conclude that the return to a year of secondary school education decreased substantially from 1915 to 1940 , similarly to the decrease in the wage ratios of table 1. 
types of industrial machinery. The same trends can be discerned in sectors such as communications, in which blue-collar radio and telephone workers were disproportionately high school graduates, and in certain types of retail trades that dealt with new, valuable, or time-sensitive products.

Some of the high school-educated workers in these industries were employed in crafts that had always demanded more education and skill, for example, electricians and machinists. ${ }^{28}$ But many were "laborers," "operatives," "drivers," and "attendants," occupations that did not require more education in all industrial and sales settings. Rather, they did so only in the new, high-technology industries.

The point is that certain firms in manufacturing, transportation, communications, public utilities, and trade saw gains to hiring more educated blue-collar employees in the $1920-50$ period. The premium to these workers had fallen, and the new high-technology firms of the era took advantage of bargain-priced employees. I am not claiming that these firms in new high-technology industries were hiring a large fraction of manufacturing workers in the 1920s and 1930 s, but they were growing, relatively, over time. The rate of return to years of schooling from the 1940 federal population census PUMS is, not surprisingly, as high for the male blue-collar workers in the new, high-tech industries as for ordinary white-collar (male) workers in general (Goldin and Katz 1998). ${ }^{29}$ But the return to years of schooling for blue-collar workers in the older industries (e.g., textiles, lumber, and clothing) was considerably lower. Capital-skill (meaning education) or technology-skill complementarity may, therefore, have been fueled by the rise of the American high school. ${ }^{30}$

\footnotetext{
${ }^{28}$ In Goldin and Katz $(1999 c)$, we present data on the premium to skill for the most skilled of the blue-collar occupations (e.g., machinist) and find that this premium also decreased around the 1910s to early 1920s and did not regain its previous level, similarly to the findings for ordinary white-collar occupations.

${ }^{29}$ Goldin and Katz (1998) look only at relatively young workers (18-34 years old) because of the biases in the census, commented on earlier, regarding grades or years of school completed.

${ }^{30}$ If manufacturing began to employ high school-educated blue-collar workers, then the alternative occupation, as in table 1, representing that of the eighth-grade graduate (all production workers), would have too high a wage. The reason is that some of the production workers would be high school graduates. The high-technology and newer industrial employments, however, were a rather small fraction of all production workers for most of the period considered. Even if a "common-laborer" wage were used as the denominator in table 1 or if the wage of production workers in an industry unaffected by these technological changes were used, the results would be about the same.
} 


\section{Why the High School Movement Began circa 1910}

One may wonder why, if the premium to educated labor was so high around 1890/95, the high school movement did not get moving until the 1910s. The high school movement required a set of preconditions. Prior to the early 1900s, high school training often meant preparation for college. For high schools to become educators of the majority of youth and spread across the American landscape, they had to be transformed into institutions that taught skills of relevance in the lives of ordinary people. Even if vocational, commercial, agricultural, and industrial courses were not offered, the high school would have to forsake a portion of its curriculum used solely for college preparation, for example, Latin, rhetoric, and ancient history. And if secondary schools were no longer primarily direct feeders into colleges and universities, what constituted a high school would have to be standardized. Not until 1902 did the Commission on Accredited Schools recommend a standard of 15 units for graduation from high school, where a unit meant four to five 45-minute periods, 35 weeks per semester (Krug 1964, p. 153).

Each state found its own way to accredit the new high schools. All of this took time. Along with the change in the function of high schools came the building of schools and the creation of districts that could educate large enough groups of youths for the modern high school to be efficient. Many states had school districts in 1900 that, while adequately sized for elementary or common schools, were too small for secondary schools. Consolidation of districts was one solution. But citizens in many states opposed legal consolidation that would also affect local control of teaching at the elementary grades. "Unionized" districts, ones that did not lose their legal basis but were formed for the sole purpose of having a joint high school, were used in a large subgroup of states. There was also the issue that some districts in a state could provide high schools for their youth, whereas others would not have high schools. Many states eventually passed the free-tuition laws mentioned above. These legal changes also took time. Thus, even if there were no changes in the underlying fundamentals, the high school movement would have been delayed until various preconditions were met.

In some states, such as those in New England, the preconditions were set down in the 1890s, if not before. In others, such as those in the Midwest and Plains states, the preconditions were formulated from the late 1890s to the mid 1910s. And in each state and region, when the preconditions for the high school movement were established, the schools were built and youths entered the schools. Stu- 
dents came in droves as though the demand for public, and possibly local private, high schools were latent. It was always there, ready to be met. I should add that it is probably no coincidence that the high school movement got underway in the United States just as the automobile, and thus the school bus, began to diffuse rapidly throughout rural America.

Finally, there was the possibility that youths and their parents needed to be convinced that high schools would offer them something of value. There is evidence that such a campaign, often termed by later historians a "campaign of propaganda," was underway in the 1910s. ${ }^{31}$ The campaign may have been successfully waged, but it appears that it was not deceptive and self-serving on the part of school administrators, as some have claimed. Rather, it appears that much of the evidence offered on the high school earnings premium, though it may not always have been estimated correctly, was similar to that found in table 1 demonstrating the substantial returns to secondary school education.

One other aspect of the dating of the high school movement should be mentioned, although the underlying data are less certain than those in table 1 . What evidence does exist on the ratio of whitecollar to production worker earnings indicates that it was somewhat lower in the pre-1890 period. The evidence is based on the annual wages for civilian clerks who worked for the U.S. Army at federal forts in the 1850s relative to wages for production workers in the same years. The ratio of their earnings was 2.1 in the $1850 \mathrm{~s}^{32}$ These clerks, however, were not the specialized ordinary white-collar workers of the twentieth century. Rather, they were often a combination of business manager, bookkeeper, and clerk. The comparison with the later data must be made to some combination of the upper echelon of those included in table 1 . If they were bookkeepers, the ratio for comparison would be 2.278 in 1895 . And if they were business managers, the ratio for comparison would be 4.35 in $1909 .{ }^{33}$ Thus the earnings ratio in the 1850 s appears to have been smaller, possibly much smaller, than for the early $1900 \mathrm{~s}$.

${ }^{31}$ See Ellis (1917) for a description of the information used in the campaign.

${ }^{32}$ The ratio of the wages of civilian "clerks" to those of common laborers nationwide was 2.1 in the $1850 \mathrm{~s}$ and was 1.9 for the forts of the northeast in the $1850 \mathrm{~s}$ (Margo 1999, chap. 7). Margo also shows that common-laborer wages were about equal to those of factory workers in the 1850s (chap. 4), although they would have been less than an average of wages of operatives and craft workers.

${ }^{33}$ In 1909, male supervisors and managers were 25 percent of the total clerical plus managerial (male) staff in manufacturing. Average earnings were $\$ 1,491$ for both groups combined and $\$ 1,058$ for the ordinary clerks (males). Thus the male supervisors and managers must have earned $\$ 2,790$. Production workers (male) in 1909 earned $\$ 641$. Thus the ratio was 4.353 . The data on bookkeepers are taken from Goldin and Katz $(1995,1999 c)$. 
Thus the fundamentals may have changed sometime just prior to 1890. The emergence of big business in manufacturing, finance, retail sales, and other sectors with its large demands for white-collar, thus educated, workers may have increased their relative wage. The foundation for the high school movement, therefore, may have been triggered by an increase in the demand for more educated workers.

\section{Egalitarianism and the Returns to Education}

The high school movement in the United States was like none other in the world at the time and for long after. The movement led to an enormous entry of young people into various occupations in America that had previously been, in the words of Paul Douglas (1930), the realm of "noncompeting groups." High schools spread first in areas of the nation that were relatively rich and were, moreover, relatively homogeneous in their affluence. Egalitarianism, therefore, begot equality. Areas with greater equality of wealth and income created institutions to stave off potential inequality. The South and the industrial areas of the North and Midwest had lower rates of high school enrollment and graduation than the Plains states and the Far West. Part of the difference was due to the lower demand for schooling among youths having higher opportunity costs in industry and agriculture. But much was due to a general commitment to high-quality public education in areas of the country having the greatest equality of wealth and income and some of the highest levels, per capita.

With the extraordinary expansion of secondary schooling came a reduction in the premium to more educated labor. The estimates presented above suggest that the high school earnings premium fell by $37 \log$ points from the 1890s to 1939, yet for most groups remained substantial on the eve of World War II. ${ }^{34}$ As the premium fell, the demand for educated labor rose in sectors, such as manufacturing, that had once devised means for doing without skilled labor. And the first "information revolution" in the office also served to shift out the demand for educated labor. Even though the supply of high school-educated youths continued to soar, the education premium did not again fall until the 1940s (Goldin and Margo 1992).

A similar story can be told for many European countries, although

${ }^{34}$ The ratio for clerks and supervisors relative to production workers was 2.392 in $1890 / 95$ and was 1.656 in 1939 ; thus $\log _{e}(2.392 / 1.656)=0.37$. I chose the data in col. 3 of table 1 because they more fully reflect the full returns to education since they include white-collar occupations into which the ordinary white-collar workers were often advanced. 
it would occur some 30 years later. British secondary schooling, for example, did not take off until after World War II, when, with the passage of the Education Act of 1944, secondary schooling became fully funded at public expense. The premium to clerical and other white-collar employment in Britain plummeted in the 1950s (Brown 1977), similarly to its swift effects in the United States during the 1910-30 period, as demonstrated in table 1 . The fact that wage differentials between ordinary white-collar and production workers remained substantial in other countries until their high school movements got underway reinforces the notion that the increase in the supply of educated workers, and not various technological changes or a downgrading in skills, led to the reduction in the premium. The returns to secondary education were substantial prior to the increase in high schools throughout the developed world.

Why Britain and most other European countries were so late in their high school movements may be rooted in their greater historic levels of inequality and the elitist features of their educational systems, such as limited university training and rigid tracking at the elementary school level. The differences across countries in the diffusion of publicly funded secondary school education are, most likely, due to the same factors that can be observed within the United States during the 1910-40 period: lower wealth and income, and a greater inequality of its distribution. Inequality may have been endogenous and self-perpetuating for some time, and the same may have been true of egalitarianism.

\section{References}

Becker, Gary S. Human Capital: A Theoretical and Empirical Analysis, with Special Reference to Education. 3d ed. Chicago: Univ. Chicago Press (for NBER), 1993.

Beniger, James R. The Control Revolution: Technological and Economic Origins of the Information Society. Cambridge, Mass.: Harvard Univ. Press, 1986.

Brown, E. Henry Phelps. The Inequality of Pay. Oxford: Oxford Univ. Press, 1977.

Burdge, Howard G. Our Boys: A Study of the 245,000 Sixteen, Seventeen, and Eighteen Year Old Employed Boys of the State of New York. Albany: Lyon, 1921.

Cortada, James W. Before the Computer: IBM, NCR, Burroughs, and Remington Rand and the Industry They Created, 1865-1956. Princeton, N.J.: Princeton Univ. Press, 1993.

Douglas, Paul H. Real Wages in the United States, 1890-1926. Boston: Houghton Mifflin, 1930.

Edgerton, A. H., and Cunliffe, R. B. "A Public School Program for Collecting and Using Occupational Information." In The Twenty-Third Yearbook of the National Society for the Study of Education. Part 2. Vocational Guidance and Vocational Education for the Industries, edited by Guy M. Whipple. Bloomington, Ill.: Public School Pub. Co., 1924. 
Ellis, A. Caswell. “The Money Value of Education.”' Bull. no. 22. Washington: Dept. Interior, Bur. Education, 1917.

Epple, Dennis, and Romano, Richard E. "Ends against the Middle: Determining Public Service Provision When There Are Private Alternatives." J. Public Econ. 62 (November 1996): 297-325.

Fernandez, Raquel, and Rogerson, Richard. "On the Political Economy of Education Subsidies." Rev. Econ. Studies 62 (April 1995): 249-62.

Goldin, Claudia. "Appendix to: 'How America Graduated from High School, 1910 to 1960': Construction of State-Level Secondary School Data." Historical Working Paper no. H0057. Cambridge, Mass.: NBER, June 1994.

- "America's Graduation from High School: The Evolution and Spread of Secondary Schooling in the Twentieth Century." J. Econ. Hist. 58 (June 1998): 345-74.

Goldin, Claudia, and Katz, Lawrence F. "The Decline of Noncompeting Groups: Changes in the Premium to Education, 1890 to 1940." Working Paper no. 5202. Cambridge, Mass.: NBER, August 1995.

_. "Technology, Skill, and the Wage Structure: Insights from the Past." A.E.R. Papers and Proc. 86 (May 1996): 252-57.

— . "Why the United States Led in Education: Lessons from Secondary School Expansion, 1910 to 1940.” Working Paper no. 6144. Cambridge, Mass.: NBER, August 1997.

—. "The Origins of Technology-Skill Complementarity." Q.J.E. 113 (June 1998): 693-732.

- "Education and Income in the Early Twentieth Century: Evidence from the Prairies.” Working Paper no. 7217. Cambridge, Mass.: NBER, July 1999. (a)

_ "Human Capital and Social Capital: The Rise of Secondary Schooling in America, 1910 to 1940." J. Interdisciplinary Hist. 29 (Spring 1999): 683-723. (b)

—. "The Returns to Skill in the United States across the Twentieth Century.'” Working Paper no. 7126. Cambridge, Mass.: NBER, May 1999. (c)

Goldin, Claudia, and Margo, Robert A. "The Great Compression: The Wage Structure in the United States at Mid Century.' Q.J.E. 107 (February 1992): 1-34.

Gorseline, Donald Eugene. The Effect of Schooling upon Income. Bloomington: Indiana Univ., Grad. Council, 1932.

Griliches, Zvi, and Chamberlain, Gary. "Unobservables with a VarianceComponents Structure: Ability, Schooling and the Economic Success of Brothers.' Internat. Econ. Rev. 16 (June 1975): 422-49.

Krug, Edward A. The Shaping of the American High School, 1880-1920. Madison: Univ. Wisconsin Press, 1964.

Margo, Robert A. Wages and Labor Markets in the United States, 1820-1860. Chicago: Univ. Chicago Press (for NBER), 1999.

Mincer, Jacob A. Schooling, Experience, and Earnings. New York: Columbia Univ. Press (for NBER), 1974.

Nichols, Frederick G. A New Conception of Office Practice Based on an Investigation of Actual Office Requirements. Cambridge, Mass.: Harvard Univ. Press, 1927.

Peltzman, Sam. "The Effect of Government Subsidies-in-Kind on Private Expenditures: The Case of Higher Education.' J.P.E. 81 (January/February 1973): 1-27. 
Poterba, James M. "Demographic Structure and the Political Economy of Public Education." J. Policy Analysis and Management 16 (Winter 1997): 48-66.

Ringer, Fritz K. Education and Society in Modern Europe. Bloomington: Indiana Univ. Press, 1979.

Stiglitz, Joseph E. "The Demand for Education in Public and Private School Systems."'J. Public Econ. 3 (November 1974): 349-85.

Trow, Martin. "The Second Transformation of American Secondary Education." Internat. J. Comparative Sociology 2 (September 1961): 144-66.

U.S. Bureau of the Census. Historical Statistics of the United States from Colonial Times to 1970. Washington: Government Printing Office, 1975.

U.S. Congress. Report of Wage and Personnel Survey, Field Survey Division: Personnel Classification Board. 70th Congress, 2d sess. House Document no. 602. Washington: Government Printing Office, 1929.

U.S. Department of Education. National Center for Education Statistics. 120 Years of American Education: A Statistical Portrait, edited by T. Snyder. Washington: Government Printing Office, 1993.

U.S. Department of the Interior. Bureau of Education. Biennial Survey of Education, 1922-1924. Bull. no. 23. Washington: Government Printing Office, 1927.

- Biennial Survey of Education, 1924-1926. Bull. no. 25. Washington: Government Printing Office, 1928.

Yates, JoAnne. Control through Communication: The Rise of System in American Management. Baltimore: Johns Hopkins Univ. Press, 1989. 